Original article

\title{
Effect of communal piped water supply on pattern of water use and transmission of schistosomiasis haematobia in an endemic area of Kenya
}

\author{
Mayumi Abe ${ }^{1}$, Ngethe D. Muhoho ${ }^{2}$, Toshihiko Sunahara ${ }^{3}$, Kazuhiko Moji ${ }^{4}$, Taro Yamamoto ${ }^{3}$ and Yoshiki Aoki ${ }^{{ }^{*}}$ \\ Received 1 January, 2009 Accepted 12 March, 2009 Published Online 12 June, 2009
}

\begin{abstract}
An attempt was made to examine the long-term impact of the introduction of communal piped water supply on pattern of water use and transmission of schistosomiasis haematobia in an endemic area of Kenya. In the study area, Mtsangatamu, a control program based on repeated selective mass-chemotherapy had been carried out for 6 years from 1987 to 1993 . The pre-treatment overall prevalence and intensity of infection in 1987 were 59.2\% and 10.9 eggs $/ 10 \mathrm{ml}$ of urine (Muhoho et al., 1997). During the control program, the prevalence was kept at a low range of 20 to $40 \%$ (Muhoho et al., 1994). At the end of the program, in 1994, gravity-fed water supply was provided to the village. Although the water facilities were damaged by flooding in 1998, new and further expanded gravity-fed water supply facilities consisting of 7 standpipes were introduced in 2000. The follow-up survey done in 1999 revealed reduced prevalence and intensity of infection, i.e. $23.0 \%$ and 1.2 eggs/ $10 \mathrm{ml}$ of urine (unpublished data). The present study was carried out in 2006, 6 years after the last mass-chemotherapy. Urine examination showed that the prevalence and intensity of infection had return to $52.2 \%$ and $7.4 \mathrm{eggs} / 10 \mathrm{ml}$, nearly the same level as the pre-treatment level. The results of our study demonstrated that, over the long-term, the gravity-fed water supply facilities had little impact on the overall prevalence and intensity of infection in this village. However, analysis of the spatial pattern of infection, observation of human water contact at the river and a questionnaire on water use shed light on the possible impact of water supply on human water contact. The younger people (5-19 years old) with easy access to the standpipes showed a lower prevalence and intensity of infection, while the relationship was not clear in other age groups.

The result of the questionnaire indicated that the long distance from household to standpipe was the major factor limiting the use of the communal tap water. Most of the villagers who used piped water as the main source of water lived within $800 \mathrm{~m}$ of the nearest standpipe, and villagers who used river water exclusively lived beyond that distance. Observation of water-related activities at the communal water facilities also indicated that the residents who lived near standpipes used the piped water more frequently.

The frequency of total visits to river water sites did not differ between residents who lived near and far from the standpipe. However, water contact in the form of playing, the highest risk behavior, was observed exclusively among children who lived far (>250m) from standpipes, although the number of observations was small.

The present study demonstrated that the water facilities had little effect on the dispersed population but might have a beneficial effect on some villagers given easy access to standpipes.
\end{abstract}

Key word: control of schistosomiasis haematobia, safe water supply, river-water contact, spatial analysis, Kenya

\section{INTRODUCTION}

Schistosomiasis remains one of the greatest health burdens of the world [1,2]. A recent study suggested that 8-60 million DALYs are lost to schistosomiasis worldwide [3]. The burden is concentrated in sub-Saharan Africa, where 112 million people are estimated to be infected and more than 400 million people at risk [4].

Chemotherapy is at the center of global strategies to control schistosomiasis and reduce both of morbidity and mortality [5]. Repeated chemotherapy can prevent severe pathology over the long term [6] but will not eliminate infection [7].

Since the prevention of schistosomiasis infection is

1. Department of Parasitology, Institute of Tropical Medicine, Nagasaki University, Nagasaki, Japan

2. The Eastern and Southern Africa Centre of International Parasite Control (ESACIPAC), Kenya Medical Research Institute, Nairobi, Kenya

3. Department of International Health, Institute of Tropical Medicine, Nagasaki University, Nagasaki, Japan

4. Research Institute for Humanity and Nature, Kyoto, Japan

*Corresponding author

Tel: +81958197825

Fax: +81958197824

E-mail address: aoki@net.nagasaki-u.ac.jp 
achieved by reducing contact with schistosoma-infested water, the establishment of safe water supply is an essential prerequisite for schistosomiasis control in endemic areas [8]. Thus, the East African National Programmes for the control of schistosomiasis and also soil-transmitted helminths strongly recommended efforts to increase the usage of safe water. [9].

There are several studies examined the effect of safe water supply on patterns of water contact and the transmission of schistosomiasis. Reports published to date deal with the short-term effect of water supply on water use pattern and transmission of schistosomiasis or the role of water supply in the control program based on the combination of mass chemotherapy and water supply [10-14]. The influence of a safe water supply on the various types of water contact activity depends on the sociodemographic features of the population or factors related to the quantity and quality of newly introduced sources [14-17]. In published reports, therefore, varying degrees of impact are observed [10, 15, 18-20].

Since 1981, our institutions have collaborated on a number of studies regarding schistosomiasis haematobia in Kwale, Coast Province, Kenya, under the sponsorship of Japan International Cooperation Agency (JICA) and Kenya Medical Research Institute (KEMRI). One of the research projects was the control project of schistosomiasis haematobia in Mtsangatamu village. The project was supported by JICA for 10 years from 1985 to 1995 . The infected villagers were treated with praziquantel every year from 1987 to 1993. In 1994, at the end of the project, a gravity-fed communal tap, laundry and bathing unit, and swimming pool were introduced at the center of the village. The water supply was expected to reduce human exposure to infection and maintain the transmission at a low level. Although the communal tap and the swimming pool were damaged by unexpected heavy rains in 1998, a new gravity-fed water supply consisting of 7 communal standpipes was introduced by Plan International, a global NGO, in 2000.

The present study attempted to examine the long-term impact of the introduction of the gravity-fed water supply on pattern of water use and the prevalence and intensity of infection of schistosomiasis in Mtsangatamu. To evaluate the impact of the communal piped water, the results of urine examination were compared with those of examinations conducted in 1987 and 1999 . The present study will demonstrated the long-term effect of a new water source on patterns of human water contact and transmission of schistosomiasis, that is, the extent to which the low prevalence or intensity of infection rendered by repeated selective masschemotherapy was maintained in this village.

Noda et al. [19] examined the utilization of piped water supply and river water at Mwachinga village, a village close to our study area, where the control program of schistosomiasis was carried out based on a combination of chemotherapy and safe water supply. They reported that consumption of safe water per person correlated negatively with the distance to community standpipes, and that the frequency of water contact per person showed a significantly greater decrease in households with a high consumption of piped water than in those with low consumption of piped water. These findings indicated the importance of the spatial factor in assessing the impact of safe water supply on schistosome infection. Therefore we examined the spatial pattern of infection and water use of villagers in the present study.

\section{MATERIALS AND METHODS}

\section{Study area and population}

The study was conducted in Mtsangatamu village, Kwale District in Coast Province, Kenya in 2006. Mtsangatamu is approximately $10 \mathrm{~km}$ southwest of Kwale town and $20 \mathrm{~km}^{2}$ in area. It has a tropical climate with two rainy seasons a year (April-June and November). Four rivers originating from ridges in the neighboring Shimba Hills National Forest Reserve flow through the village. According to our census of 1994 , the total population was $2,329(1,031$ in male and 1,298 in female). There were 199 households.

In the study village, treatment by praziquantel was repeated every year from 1987 to 1993 for villagers showing evidence of hematuria or eggs. In 1994, when the control program came to the end, one communal standpipe, a laundry and bathing unit, and a swimming pool were established at the edge of the village. The piped water was supplied by gravity from the spring source in the adjacent hills.

Although the standpipe and swimming pool were damaged by heavy rains in 1998, the global NGO, Plan International, provided the village with new gravity-fed water facilities consisting 7 standpipes. The standpipes were built at about $700 \mathrm{~m}$ intervals along the road. Besides the communal piped water, there were 4 households that enjoyed a safe water supply, i.e. privately piped water or tanks fed by rain.

In Mtsangatamu, prior to the introduction of selective mass-chemotherapy in 1987, the prevalence and intensity of infection were very high at $59.2 \%$ and $10.9 \mathrm{eggs} / 10 \mathrm{ml}$ of urine [21]. During the 6 years periods when selective masschemotherapy was repeated, the overall prevalence was maintained at a relatively low level ranging from 20 to $40 \%$ [22]. A follow-up survey conducted in 1999 showed that the prevalence and intensity of infection in this village remained low, i.e. $23.0 \%$ and 1.2 eggs $/ 10 \mathrm{ml}$ of urine (unpub- 
lished data). No selective mass chemotherapy was provided after the villagers were treated in 1999.

\section{Urine examination}

Urine specimens collected from villagers were examined using the modified filtration method of Peters et al. [23] in January 2006. Intensity of infection was expressed as the number of eggs/10 $\mathrm{ml}$ of urine. The geometric mean was obtained using the $n+1$ transformation for a series of egg output including zero. The subjects were asked to provided information on name, age and sex, and the household to which each subject belonged was identified in the register book revised by the 1994 census. The villagers who showed evidence of eggs or hematuria were treated with praziquantel. Haematuria was detected using reagent strips.

\section{Utilization of the piped water and river water}

A questionnaire and direct observation were implemented to document the main source of water used by the villagers for personal and domestic purposes. The observation of water use was conducted in February 2006.

1) Design and application of the questionnaire

A simple water use questionnaire was designed by our team, and interviews were conducted by trained local workers. The subjects were arbitrarily selected among adults (age $\geq 20$ ) who took the urine examination or who attended local meetings. The questionnaire was divided into a demographic section including household residence and a section concerning main source of water for personal and domestic purposes.

2) Human water contact at rivers

Human water contact at rivers was measured at 4 busy sites (Figure 1: R1-R4) by the direct observation method of Noda et al. [19]. Each site was attended by one local worker who observed and recorded the water contact behavior of the villagers from 6:00 a.m. to 6:30 p.m. in one day. The information collected was name, sex, age, household, type of activity and duration of water contact. The level of water contact for one individual during a single exposure was expressed as duration of contact (minutes) multiplied by exposed body area (whole body $=1$ ), estimated by the rule of nines.

3) Utilization of gravity-fed piped water

A local worker observed and recorded the name, sex, age, household, type of activity of villagers who used the piped water facilities as well as the amount of water consumed by the villagers at 5 water facilities. Observation was carried out at each site in one day from 6:00 a.m. to 6:30 p.m. 2 of the 7 standpipes, S-6 and S-7, provided only intermittent water supply during our survey. Observation was not conducted.

\section{Geospatial processing}

A village worker familiar with the residents in the area visited each household of the participants in the study and recorded the location with a handheld global positioning system receiver (Geko 201, Garmin) in February 2006. The location of 4 households reported by the participants in the study was not identified and so they were excluded from the spatial analysis. The location of 4 water contact sites at rivers and 7 standpipes in the village was also recorded. The shortest distance from each household to a standpipe and to a river site was calculated with the coordinates in the Universal Transverse Mercator projection.

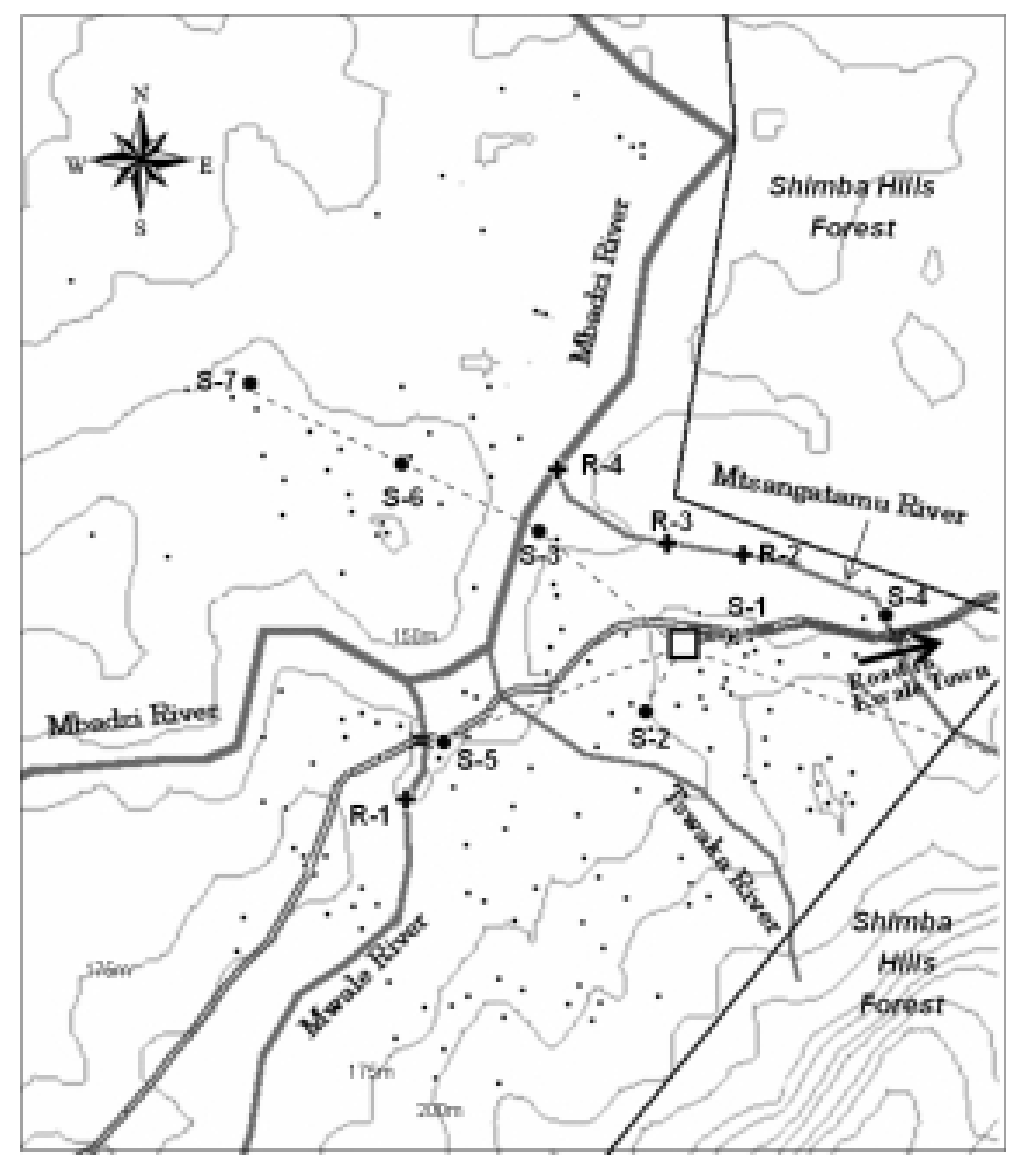

Figure 1. Study area showing the households of participants in our study in relation to the human-water contact sites at the river and community standpipes (White square: water tank, $\bullet$ S-1-S-7: community standpipes, + R-1-R-4: human-water contact sites, broken line: pipeline, dot: households of participants; there are five households beyond the north end of this map.) 


\section{Statistical analysis}

Associations of binary (positive or negative) and continuous (egg count) results of urinary test and possible risk factors were examined by logistic regression and negative binomial regression analyses, respectively. In these analyses, independent variables were chosen from sex, age, distance to the nearest standpipe, and distance to the nearest river site so that the multivariate models have the lowest Akaike's Information Criteria (AIC). Associations among categorical variables were made by the chi square test or Fischer's exact test as appropriate. The Wilcoxon rank-sum test was employed for the comparison of intensity of infection, distances, the amount of water contact and piped water consumption. Logistic regression was conducted to examine the relationship between the use of piped water and distance to the standpipe. These analyses were conducted using JMP 6 (SAS Institute) and R 2.8.1 (The R Foundation for Statistical Computing).

\section{Ethical consideration}

The ethical issues were considered and approved by Kenya-Japan Communicable Diseases Control Project of JICA and KEMRI.

\section{RESULTS}

\section{Prevalence and intensity of infection in the study area}

Urine specimens of 1,111 villagers were examined. Overall prevalence was $52.2 \%$; $54.3 \%$ in males and $50.4 \%$ in females. Intensity of infection in the community was 7.4 eggs $/ 10 \mathrm{ml}$ of urine, of $8.7 \mathrm{eggs} / 10 \mathrm{ml}$ of urine for males and $6.5 \mathrm{eggs} / 10 \mathrm{ml}$ of urine for females (Table 1).

The peak prevalence and intensity of infection occurred in children between 10 and 14 years of age, with a low prevalence and intensity of infection in the older age groups (Figure 2)

The prevalence and intensity of infection were much higher than those observed in the previous urine test in 1999 (23.0\% and $1.2 \mathrm{eggs} / 10 \mathrm{ml}$ of urine), and were at nearly the same level as the pre- treatment level in 1987 (59.2\% and 10.9 eggs $/ 10 \mathrm{ml}$ of urine).

When the results of urine examination for eggs were analyzed according to distance to the nearest standpipe, individuals aged 5-19 years old who lived within $250 \mathrm{~m}$ to the nearest standpipe showed the lower prevalence and intensity of infection (Figure 3). The relationship between the distance to the standpipe and the prevalence and intensity of infection was not clear in younger (0-4 years old) and older ( $\geq 20$ years old) age groups of subjects, whose prevalence and intensity of infection were lower. In subsequent multivariate analyses, the statistical significance of the effects of age and distance to the nearest standpipe remained after being adjusted for the other variables (Table 2).

\section{Water sources and utilization}

The villagers obtained their water from the standpipes and river for personal and domestic purposes. Table 3 summarizes the main source of water utilized by 283 interviewed individuals.

Among the 283, 89 reported piped water alone as the

Table 1 Demographic and parasitological features of subjects of urine examination in Mtsangatamu

\begin{tabular}{lcccc}
\hline Sex & $\begin{array}{c}\text { No. of } \\
\text { residents } \\
\text { examined }\end{array}$ & $\begin{array}{c}\text { Age } \\
\text { (Mean } \pm \text { SD) }\end{array}$ & Prevalnece & $\begin{array}{c}\text { Intensity of } \\
\text { infection }\end{array}$ \\
\cline { 4 - 5 } Male & 506 & $17.9 \pm 17.6$ & $54.3 \%$ & 8.7 \\
Female & 605 & $20.1 \pm 16.9$ & $50.4 \%$ & 6.5 \\
\hline Total & 1,111 & $19.1 \pm 17.3$ & $52.2 \%$ & 7.4 \\
\hline
\end{tabular}

$\dagger$ Geometric nean of the number of eggs per $10 \mathrm{ml}$

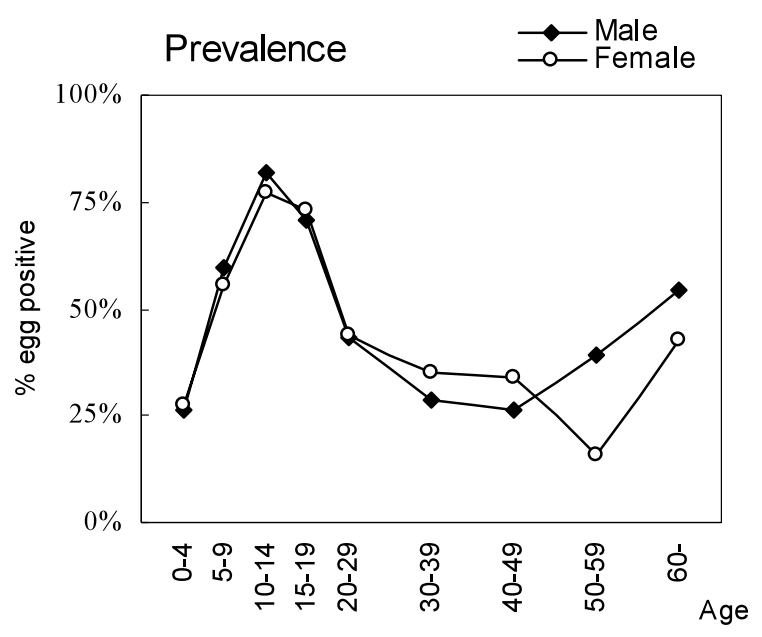

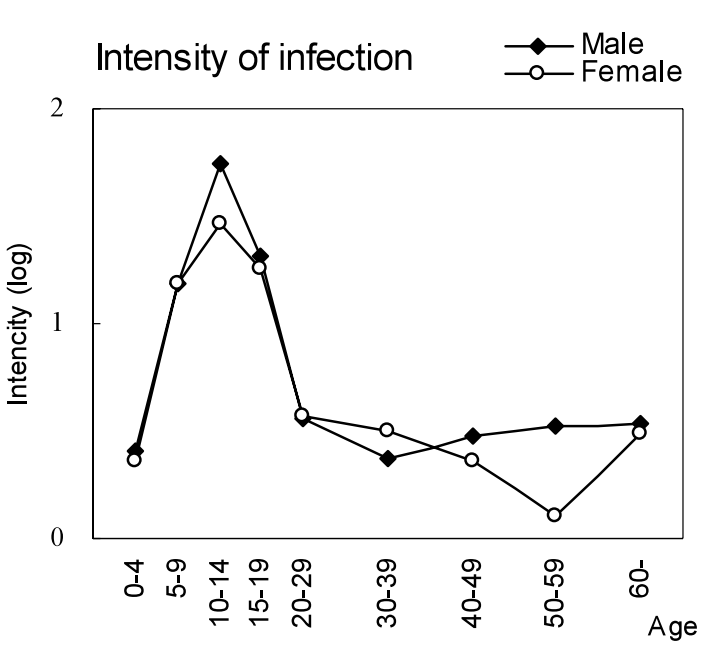

Figure 2. Prevalence and intensity of infection of schistosomiasis haematobia in Mtsangatamu in relation to age. 

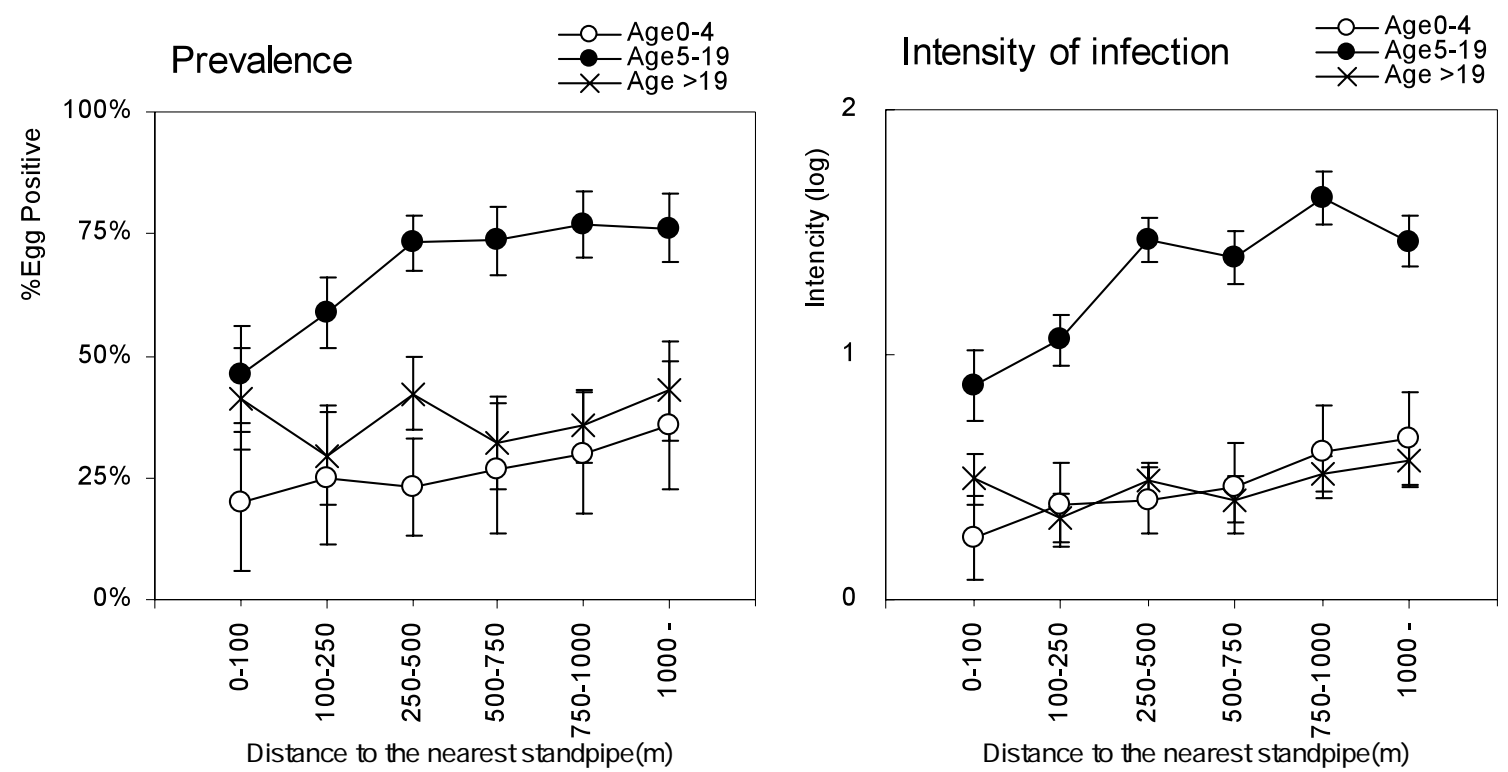

Figure 3. Prevalence and intensity of infection of schistosomiasis haematobia among the residents by age and the distance from their household to the nearest standpipe (vertical bar: SE).

source of water, 32 reported river water alone as the source, and 162 reported that they used both piped and river water.

There was no significant difference in water source by the demographic variable, except the number of members in a household. The households consisting of less than 7 family members were more likely to use piped water.

Another factor enhancing the use of communal tap water is presented in Figure 4, which shows the distribution of individuals who reported the exclusive or mixed usage of piped water and/or river water by the distance from their household to the nearest standpipe. Interestingly, most of the villagers who used piped water as the main source of water were those who lived within $800 \mathrm{~m}$ of the nearest standpipe, although some of the villagers living beyond 800 $\mathrm{m}$ also used piped water exclusively. Villagers who used river water exclusively lived beyond $800 \mathrm{~m}$. The proportion of piped water user (exclusive and mixed) was $98.1 \%$ among those living within $800 \mathrm{~m}$ of the standpipes and

Table 2. Multivariate analysis to assess the association between schistosomiasis infection and potential risk factors

\begin{tabular}{|c|c|c|c|c|c|c|}
\hline \multirow[b]{2}{*}{ Variables } & \multirow{2}{*}{$\begin{array}{c}\text { No. of } \\
\text { residents } \\
\text { examined }\end{array}$} & \multicolumn{3}{|c|}{ Infection status } & \multicolumn{2}{|c|}{ Intensity of infection } \\
\hline & & $\begin{array}{c}\text { Preva- } \\
\text { lence }\end{array}$ & $\begin{array}{c}\text { Adjusted } \\
\text { OR }^{*} \\
\end{array}$ & $(95 \% \mathrm{CI})$ & $\begin{array}{l}\text { Egg } \\
\text { Count }^{\dagger}(95 \% \mathrm{CI})\end{array}$ & $\begin{array}{l}\text { Adjusted } \\
\mathrm{RI}^{* *}(95 \% \mathrm{CI})\end{array}$ \\
\hline \multicolumn{7}{|l|}{ Sex } \\
\hline Male & 506 & $54.3 \%$ & ns & & $8.7(6.8-11.0)$ & ns \\
\hline Female & 605 & $50.4 \%$ & & & $6.5(5.2-8.1)$ & \\
\hline \multicolumn{7}{|l|}{ Age } \\
\hline $0-4$ & 171 & $26.9 \%$ & 1.00 & & $1.9(1.1-3.0)$ & 1.00 \\
\hline $5-19$ & 568 & $69.4 \%$ & 6.27 & $(4.29-9.29)$ & $22.0(17.8-27.4)$ & $3.75(2.22-6.07)$ \\
\hline$\geq 20$ & 372 & $37.6 \%$ & 1.64 & $(1.11-2.47)$ & $2.0(1.5-2.6)$ & $0.45(0.26-0.76)$ \\
\hline \multicolumn{7}{|c|}{$\begin{array}{l}\text { Distance to the } \\
\text { nearest standpipe }\end{array}$} \\
\hline$\leq 250 \mathrm{~m}$ & 283 & $43.5 \%$ & 1.00 & & $4.1(2.9-5.6)$ & 1.00 \\
\hline$>250 \mathrm{~m}$ & 828 & $55.2 \%$ & 1.99 & $(1.46-2.72)$ & $9.0(7.5-10.9)$ & $2.27(1.51-3.35)$ \\
\hline \multicolumn{7}{|c|}{$\begin{array}{l}\text { Distance to the } \\
\text { nearest river site }\end{array}$} \\
\hline$\leq 1 \mathrm{~km}$ & 793 & $52.6 \%$ & ns & & $7.1(5.2-9.5)$ & ns \\
\hline$>1 \mathrm{~km}$ & 318 & $51.3 \%$ & & & $7.6(6.2-9.2)$ & \\
\hline
\end{tabular}

${ }^{*}$ Odds Ratio; Multiple logistic regression with age and distance to the nearest standpipe

$\dagger$ Geometric mean of the number eggs per $10 \mathrm{ml}$ urine

${ }^{* *}$ Relative intensity; multiple negative binomial regression with age and distance to standpipe. 
Table 3 Relative usage of piped water and river water among interviewed individuals by the demographic variables

\begin{tabular}{|c|c|c|c|c|c|}
\hline \multirow[b]{2}{*}{ Demographic variables } & \multirow{2}{*}{$\begin{array}{c}\text { No. of } \\
\text { persons } \\
\text { answering }\end{array}$} & \multicolumn{3}{|c|}{ No. of persons who reported use } & \multirow{2}{*}{$\begin{array}{c}\text { Statistical } \\
\text { significance }\end{array}$} \\
\hline & & $\begin{array}{c}\text { Piped water } \\
\text { exclusively }(\%)\end{array}$ & $\begin{array}{l}\text { Both piped and } \\
\text { river water }(\%)\end{array}$ & $\begin{array}{c}\text { River water } \\
\text { exclusively }(\%)\end{array}$ & \\
\hline \multicolumn{6}{|l|}{ Sex } \\
\hline Male & 81 & $25(30.9)$ & $45(55.6)$ & $11(13.6)$ & ns \\
\hline Female & 198 & $61(30.8)$ & $116(58.6)$ & $21(10.6)$ & \\
\hline \multicolumn{6}{|l|}{ Ethnicity } \\
\hline Duruma & 82 & $25(30.5)$ & $48(58.5)$ & $9(11.0)$ & ns \\
\hline Others & 196 & $62(31.6)$ & $112(57.1)$ & $22(11.2)$ & \\
\hline \multicolumn{6}{|l|}{ Religion } \\
\hline Traditional & 14 & $4(28.6)$ & $8(57.1)$ & $2(14.3)$ & $-\S$ \\
\hline Others & 266 & $85(32.0)$ & $151(56.8)$ & $30(11.3)$ & \\
\hline \multicolumn{6}{|l|}{ Educational back ground } \\
\hline Primary school & 160 & $53(33.1)$ & $93(58.1)$ & $14(8.8)$ & ns \\
\hline No & 120 & $36(30.0)$ & $67(55.8)$ & $17(14.2)$ & \\
\hline \multicolumn{6}{|l|}{$\begin{array}{l}\text { Number of members } \\
\text { in a household }\end{array}$} \\
\hline 1-7 persons & 172 & $68(39.5)$ & $90(52.3)$ & $14(8.1)$ & $\mathrm{p}<0.01$ \\
\hline$\geqq 8$ persons & 104 & $21(20.2)$ & $69(66.3)$ & $14(13.5)$ & \\
\hline
\end{tabular}

$\dagger$ Number of persons answering was 283. Some of them did not answer all the questions

$\S$ Not tested because of the small sample size of traditional religion
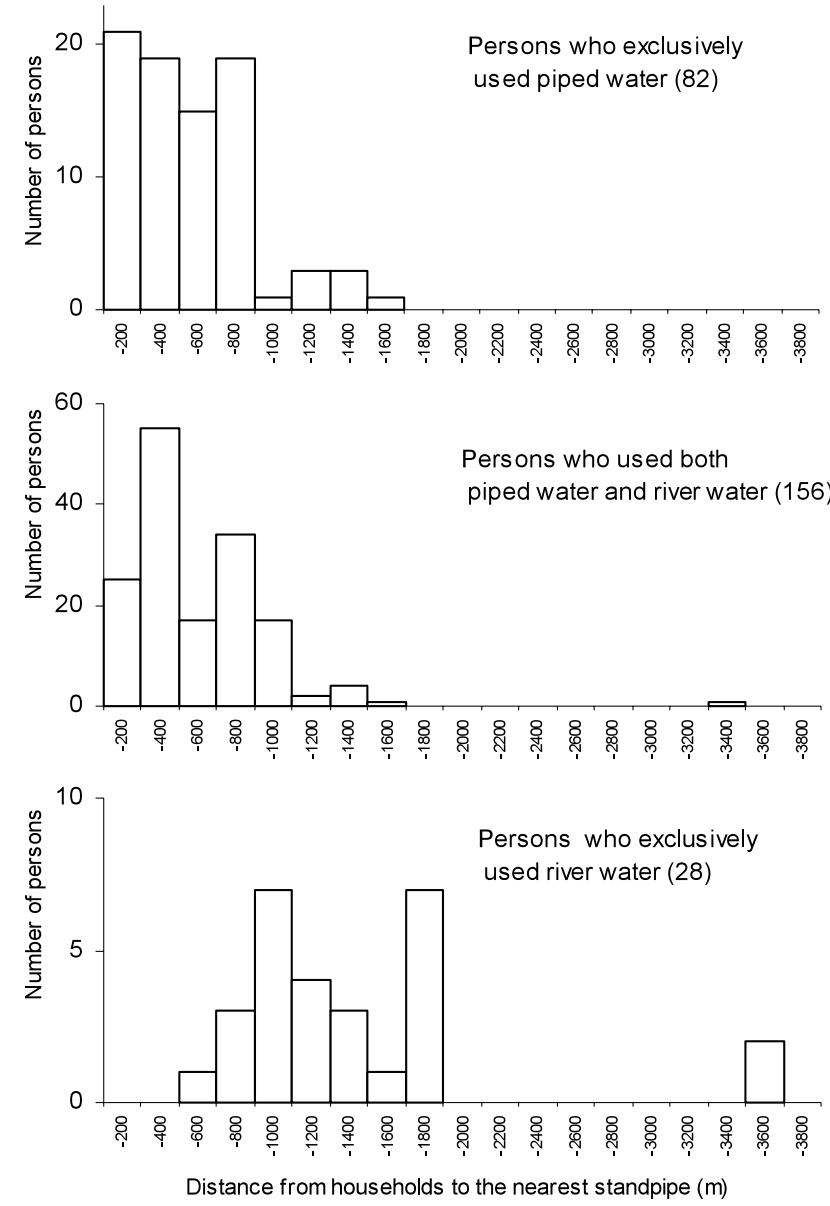

Figure 4. Distribution of interviewed individuals who reported exclusive or mixed usage of piped water and/or river water by the distance from their households to the nearest standpipe. Out of 283 interviewed individuals, 17 were excluded because the location of their households could not be ascertained.
$57.9 \%$ among those living beyond that distance.

\section{Water contact of residents at the river}

A total of 110 residents (63 were female) were observed to be in contact with water at the river. The adult population (considered 20 years of age and older) accounted for $47.2 \%$ of all persons observed. The major water contact activities were bathing, collecting water, crossing and washing clothes.

Table 4 presents the frequency of water contact activities by the distance to the nearest standpipe. In total, residents who lived near standpipes $(\leq 250 \mathrm{~m})$ and those who lived far $(>250 \mathrm{~m})$ from standpipes exhibited 55 and 142 activities, respectively. Out of 1,111 participants in the urine examination, 283 lived within $250 \mathrm{~m}$ of the nearest

Table 4 Frequency of water contacts at river by the activity and the distance from the household to the nearest standpipe

\begin{tabular}{lcccc}
\hline & \multicolumn{4}{c}{ Location of household } \\
\cline { 2 - 3 } Activities & \multicolumn{2}{c}{ Within 250 m from standpipe } & \multicolumn{2}{c}{ beyond 250 m } \\
\cline { 2 - 3 } \cline { 5 - 6 } & $\begin{array}{c}\text { No. of } \\
\text { persons } \\
\text { observed }\end{array}$ & $\begin{array}{c}\text { Total } \\
\text { frequency }\end{array}$ & $\begin{array}{c}\text { No. of } \\
\text { persons } \\
\text { observed }\end{array}$ & $\begin{array}{c}\text { Total } \\
\text { frequency }\end{array}$ \\
\hline Playing & 1 & $1(1.8)$ & 15 & $18(12.7)$ \\
Bathing & 11 & $11(20.0)$ & 30 & $30(21.1)$ \\
Washing & 9 & $9(16.4)$ & 10 & $11(7.7)$ \\
Collection & 11 & $14(25.5)$ & 43 & $52(36.6)$ \\
Fording & 16 & $20(36.4)$ & 22 & $31(21.8)$ \\
\hline Total & $31^{\ddagger}$ & 55 & $79^{\ddagger}$ & 142 \\
\hline
\end{tabular}

ๆ figures in parenthesis indicate percentage

$\ddagger$ Some persons presented more than one activity 
standpipe and 828 lived beyond that distance. Based on the assumption that the distribution of the participants represents that of the total village population of and that all villagers make water contact at the river at the same frequency, we calculated the expected ratio of water contact between residents living close to and far from the standpipes. The expected value, 50.2: 146.8, was not different significantly from the observed value, 55:142. $\left(\chi^{2}=0.52, \mathrm{df}=1, \mathrm{p}=0.47\right)$. The frequency of water contact at river sites, therefore, did not differ between residents living near and far from standpipes.

However, the frequency of the five categories of activity was significantly different between the two groups $\left(\chi^{2}=\right.$ $12.48, \mathrm{df}=4, \mathrm{p}=0.014)$. It is noteworthy that 15 out of 16 persons who played at the river lived beyond $250 \mathrm{~m}$ from the nearest standpipe (Table 4).

The amount of water contact was larger among residents who lived far from standpipes, especially in individuals 5-19 years of age (Table 5; $\mathrm{p}=0.057$ ). It was attributable to the fact that playing was the largest water contact activity.

\section{Usage of piped water}

A total of 281 residents, of which 215 (76.5\%) were female, were observed at standpipes. The adult population accounted for $41.6 \%$ of all persons observed.

Table 6 presents the frequency of activities of residents at standpipes by the distance to the nearest standpipe. In total, residents who lived near standpipes $(\leq 250 \mathrm{~m})$ and those who lived far $(>250 \mathrm{~m}$ ) from standpipes exhibited 241 and 285 activities, respectively. Again, we calculated the expected ratio of activity at standpipe between residents who lived close to and far from a standpipe. The expected value, 134.0:392.0, was significantly different from the observed value $\left(\chi^{2}=67.9, \mathrm{df}=1, \mathrm{p}<0.001\right)$, that is, the residents who lived near standpipes used piped water more frequently. The frequency of the 3 categories of activity did not significantly differ between the two groups $\left(\chi^{2}=2.55\right.$, df $=2, \mathrm{p}=$ 0.28). Collection of water was the most frequently observed activity in both groups.

The average amount of water consumed by the villagers was 10.8 litters for bathing, 44.7 litters for washing and 12.6 litters for drawing water. Table 7 shows the amount of water consumed by the residents by age and distance from

Table 5 Frequency and amount of water contact at river by age and distance from the household to the nearest standpipe

\begin{tabular}{|c|c|c|c|c|c|c|}
\hline \multirow[b]{3}{*}{ Age } & \multicolumn{6}{|c|}{ Location of household } \\
\hline & \multicolumn{3}{|c|}{ Within $250 \mathrm{~m}$ from standpipe } & \multicolumn{3}{|c|}{ beyond $250 \mathrm{~m}$} \\
\hline & $\begin{array}{c}\text { No. of } \\
\text { persons } \\
\text { observed }\end{array}$ & $\begin{array}{l}\text { Total } \\
\text { Freq- } \\
\text { uency }\end{array}$ & $\begin{array}{c}\text { Amount of } \\
\text { water contact }^{\S} \\
\text { (Range) }\end{array}$ & $\begin{array}{c}\text { No. of } \\
\text { persons } \\
\text { observed }\end{array}$ & $\begin{array}{l}\text { Total } \\
\text { Freq- } \\
\text { uency }\end{array}$ & $\begin{array}{c}\text { Amount of } \\
\text { water contact }^{\S} \\
\text { (Range) }\end{array}$ \\
\hline $0-4$ & 0 & 0 & - & 1 & 1 & 0.9 \\
\hline $5-19$ & 15 & 26 & $1.9(0.2-31.0)$ & 42 & 85 & $5.7(0.2-60.0)$ \\
\hline$>19$ & 16 & 29 & $1.6(0.2-12.0)$ & 36 & 56 & $1.8(0.2-8.9)$ \\
\hline Total & 31 & 55 & $1.6(0.2-31.0)$ & 79 & 142 & $3.3(0.2-60.0)$ \\
\hline
\end{tabular}

Table 6 Frequency of water-related behaviors at standpipes by the distance from the household to the nearest standpipe

\begin{tabular}{lccccc}
\hline & \multicolumn{4}{c}{ Location of household } \\
\cline { 2 - 5 } Activities & Within 250 m from standpipe & \multicolumn{2}{c}{ beyond 250 m } \\
\cline { 2 - 5 } \cline { 5 - 6 } & $\begin{array}{c}\text { No. of } \\
\text { persons } \\
\text { observed }\end{array}$ & $\begin{array}{c}\text { Total } \\
\text { frequency }\end{array}$ & $\begin{array}{c}\text { No. of } \\
\text { persons } \\
\text { observed }\end{array}$ & $\begin{array}{c}\text { Total } \\
\text { frequency }\end{array}$ \\
\hline Bathing & 13 & $14(5.8)$ & 21 & $23(8.1)$ \\
Washing & 5 & $5(2.1)$ & 11 & $11(3.9)$ \\
Collection & 98 & $222(92.1)$ & 170 & $251(88.1)$ \\
\hline Total & $105^{\ddagger}$ & 241 & $176^{\ddagger}$ & 285 \\
\hline
\end{tabular}

I figures in parenthesis indicate percentage

$\ddagger$ Some persons presented more than one activity 
their household to the nearest standpipe. The adults used a larger amount of water than children. There was no difference in the amount of water consumed by residents living close to and far from the standpipes.

Table 8 shows the villagers' comments on the piped water supply. A majority of the piped water users replied favorably. They were generally satisfied with the easy access to standpipes, the cleanliness of the water and the reasonable charge, although a few users complained of the charge for water and the distance of facilities from their households. One of the problems they encountered was the frequent interruption of the water supply due to the shortage of water in the tank. The people who did not use the pipe water complained of the long distance between the facilities and their households but did not complain of the charge for water.

Table 7 Frequency of visit and consumption of water at the standpipes by age and the distance from the household to the nearest standpipe

\begin{tabular}{|c|c|c|c|c|c|c|}
\hline \multirow[b]{3}{*}{ Age } & \multicolumn{6}{|c|}{ Location of household } \\
\hline & \multicolumn{3}{|c|}{ Within $250 \mathrm{~m}$ from standpipe } & \multicolumn{3}{|c|}{ beyond $250 \mathrm{~m}$} \\
\hline & $\begin{array}{c}\text { No. of } \\
\text { persons } \\
\text { observed }\end{array}$ & $\begin{array}{l}\text { Total } \\
\text { Freq- } \\
\text { uency }\end{array}$ & $\begin{array}{l}\text { Consumption of } \\
\text { water per person }^{\dagger} \\
\text { (L) (Range) }\end{array}$ & $\begin{array}{c}\text { No. of } \\
\text { persons } \\
\text { observed }\end{array}$ & $\begin{array}{l}\text { Total } \\
\text { Freq- } \\
\text { uency }\end{array}$ & $\begin{array}{l}\text { Consumption of } \\
\text { water per person }^{\dagger} \\
\text { (L) (Range) }\end{array}$ \\
\hline $0-4$ & 6 & 6 & $5.3(3-10)$ & 2 & 3 & $4.2(3-6)$ \\
\hline $5-19$ & 72 & 169 & $17.6(3-170)$ & 84 & 122 & $12.7(1-100)$ \\
\hline$>19$ & 27 & 66 & $39.2(8-260)$ & 90 & 160 & $29.3(1-140)$ \\
\hline Total & 105 & 241 & $20.2(3-260)$ & 176 & 285 & $19.2(1-140)$ \\
\hline
\end{tabular}

Table 8 Comments of villagers regarding the communal piped water facilities

\begin{tabular}{|c|c|c|c|c|}
\hline \multirow[b]{2}{*}{ Question } & \multicolumn{2}{|c|}{ Piped-water user } & \multicolumn{2}{|c|}{ Exclusive river-water user } \\
\hline & $\begin{array}{c}\text { No. of } \\
\text { individuals } \\
\text { interviewed }\end{array}$ & $\begin{array}{c}\text { No. of } \\
\text { individuals } \\
\text { admitted (\%) }\end{array}$ & $\begin{array}{c}\text { No. of } \\
\text { individuals } \\
\text { interviewed }\end{array}$ & $\begin{array}{c}\text { No. of } \\
\text { individuals } \\
\text { admitted }(\%)\end{array}$ \\
\hline Expression of satisfaction & 251 & $227(90.4)$ & 30 & $0 \quad(0.0)$ \\
\hline \multicolumn{5}{|l|}{ A source of satisfaction ${ }^{\dagger}$} \\
\hline Easy access to water & 227 & $176(77.5)$ & 0 & - \\
\hline Clean water & 227 & $163(71.8)$ & 0 & - \\
\hline Others & 227 & $5(2.2)$ & 0 & - \\
\hline \multicolumn{5}{|l|}{ Reason for dissatisfaction $^{\dagger}$} \\
\hline Far from the standpipe & 24 & $17(70.8)$ & 30 & $29 \quad(96.7)$ \\
\hline Unclean water & 24 & $6(25.0)$ & 30 & $1(3.3)$ \\
\hline Others & 24 & 4 (16.7) & 30 & $0 \quad(0.0)$ \\
\hline Problem of piped water supply & 249 & $95 \quad(38.2)$ & 29 & 8 (27.6) \\
\hline \multicolumn{5}{|l|}{ Source of the problem ${ }^{\ddagger}$} \\
\hline Interrupted supply & 95 & $83 \quad(87.4)$ & 8 & $0 \quad(0.0)$ \\
\hline Breakdown of the tap & 95 & $15(15.8)$ & 8 & $0 \quad(0.0)$ \\
\hline Far from the standpipe & 95 & $15(15.8)$ & 8 & $8(100.0)$ \\
\hline Others & 95 & $5(5.3)$ & 8 & $0 \quad(0.0)$ \\
\hline \multicolumn{5}{|l|}{ Charge for piped water } \\
\hline Cheap & 245 & $32(13.1)$ & 12 & $4 \quad(33.3)$ \\
\hline Acceptable & 245 & $181(73.9)$ & 12 & $8 \quad(66.7)$ \\
\hline Expensive & 245 & 32 (13.1) & 12 & $0 \quad(0.0)$ \\
\hline Payment ${ }^{\S}$ & 250 & $248 \quad(99.2)$ & - & \\
\hline
\end{tabular}

$\dagger$ Multiple answer

$\ddagger$ Free answer

$\S$ User of the facility only. 


\section{DISCUSSION}

The present study aimed to examine the extent to which the low prevalence of schistosomiasis haematobia rendered by the repeated chemotherapy over a 6-year period was maintained by the safe water supply provided at the end of the mass-chemotherapy control program at Mtsangatamu village, Kwale, Kenya. To evaluate the impact of the safe water supply, it was necessary to assess the changes in $S$. haematobium infection in this village.

In our study area, Mtsangatamu, the overall prevalence was maintained at relatively low level of 20 to $40 \%$ during the period of repeated chemotherapy from 1987 to 1993 [22], and the results of a follow-up survey done in 1999 showed a prevalence as low as $23 \%$ (unpublished data). The present study was carried out in 2006, 6 years after the final mass chemotherapy given to the villagers and the establishment of an extended water supply.

The overall prevalence and intensity of infection observed in this village in 2006 were much higher than those in 1999 and had in fact returned to nearly the same level as the pre-treatment level in 1987 . The results of our study demonstrated, with regard to the long term effect, that supplying safe water via gravity-fed communal standpipes had little impact on $S$. haematobium transmission in the study area as a whole. The study area is $20 \mathrm{~km}^{2}$ and has more than 2,000 residents. The 7 standpipes might not be enough to provide a volume of safe water sufficient to maintain the low level of water contact at the river and, consequently, to maintain the prevalence at low levels. The frequent interruption of the safe water supply may be another factor behind the negligible impact.

However, the spatial analysis of infection indicated that prevalence and intensity of infection were low among individuals 5-19 years of age who were susceptible to schistosome infection and lived within $250 \mathrm{~m}$ of the nearest standpipe. This result suggests that the supply of piped water exerted partially beneficial effect reducing of the risk of infection among young people. The fact that the prevalence and intensity of infection was significantly associated with the distance between household and standpipe was established by the multivariate analysis. The prevalence and intensity of infection were relatively low among adults who lived far from the standpipes and those who lived the near standpipes, suggesting that the beneficial effect of piped water, if any, was significant for young individuals alone who are sensitive to infection and had heavy contact with river water.

It is of interest in this connection to note that safe water supply can change villagers' behavior in terms of water use. In the village of Kwale, Mwachinga, Noda et al. [19] reported that a significant decrease in human water contact at the river was seen only when people used more than 1,000 liters of piped water per person per year. More interestingly, people who lived more than $800 \mathrm{~m}$ from standpipes were unlikely to reduce river water contact (Shimada, personal communication).

In the present study, although the subjects of the questionnaire were limited to adults, the people who lived close to standpipes were likely to use them. A majority of users of the piped water were satisfied with the communal piped water facilities, reporting the easy access to standpipes, cleanliness of water and reasonable charge for water as advantage. A few users of the piped water complained of the long distance of the facilities from their households and the expensive charge for water. People who did not use the piped water complained of the distance between the household and the standpipe, but they did not complain of the charge for the water. The limited number of water facilities for a dispersed population was the basic problem limiting widespread use of the piped water. Figure 5 presents the logistic regression curves predicting the proportion of exclusive and partial piped water users by the distance to the nearest standpipe. The proportion of residents who use piped water at least partially $(\mathrm{p})$ fitted well to logistic regression: $\log \{\mathrm{p} /(1-\mathrm{p})\}=5.066-3.709 \cdot \mathrm{X}$ (X: distance in kilometer, $\left.\mathrm{r}^{2}=0.337, \mathrm{p}<0.001\right)$. According to this model, more than $98 \%$ of the residents who lived within $250 \mathrm{~m}$ of a standpipe used the standpipe. The fact that people who lived close to the standpipes frequently used piped water was also confirmed by direct observation.

In the present study, we did not obtain evidence to

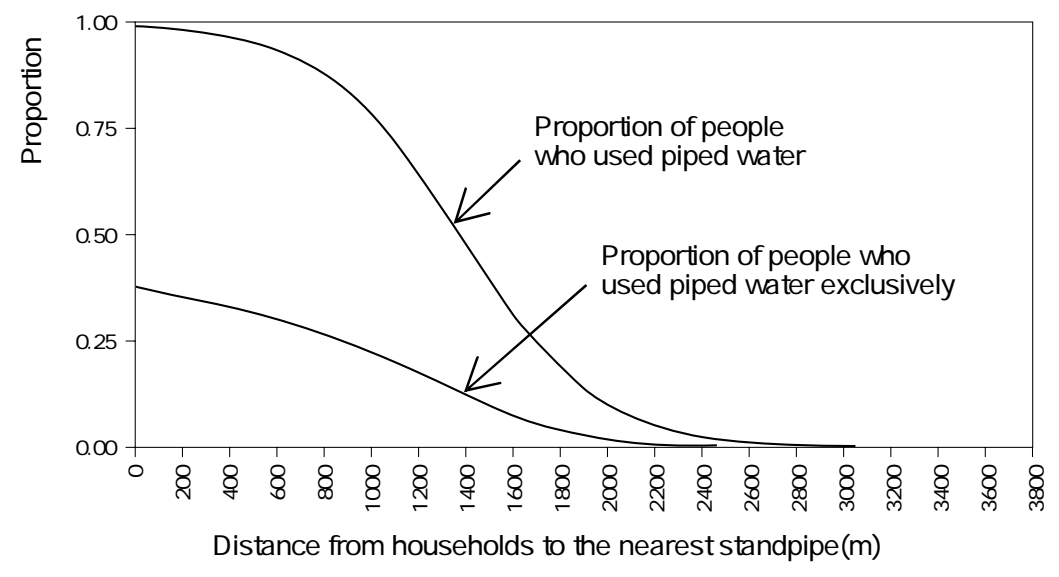

Figure 5. Logistic regression curves that predict proportions of exclusive and partial pipe-water users by the distance to the nearest standpipe 
show that the people who used piped water reduced their contact with river water, A finding that may be due to the small sample size subjected to direct observation. It appeared that the frequency of the visits to river water sites did not differ greatly between residents who lived near to and far from standpipes. However, it is noteworthy that, although the number of observations was small, water contact in the form of playing (including swimming) which accounts for the highest risk of infection, was observed exclusively among children who lived far $(>250 \mathrm{~m})$ from standpipes. It is interesting to note that the prevalence and intensity of infection in this village maintained low over a period of 6 years (1993 to 1999) after the selective mass-treatment was interrupted. Although the facilities were damaged by flooding in 1998, the initial water facilities consisted of one standpipe, a laundry and bathing unit, and a swimming pool at the center of the village. The water facilities provided in 2000 consisted of 7 standpipes in the village but lacked the other water-related facilities, suggesting that the swimming pool, laundry and bathing unit played an important role in the reduction of river-water contact among villagers between 1993 and 1999.

In conclusion, the present study showed that the overall effect of gravity-fed safe water supply on schistosomiasis infection, if any, was limited to young people who lived close to the standpipes. There are several reports that dealt with the success of water supply in the control of schistosomiasis [10, 15, 24]. In our study area, a water supply sufficient to meet domestic requirements is necessary to maintain the prevalence of $S$. haematobium infection at low levels, including the construction of more community standpipes located at least $250 \mathrm{~m}$ from all households, the provision of laundry and shower units, restoration of the swimming pool, systematic health education, and, most importantly, the resumption of mass chemotherapy among villagers.

\section{ACKNOWLEDGEMENTS}

This study is a follow-up of the control program of schistosomiasis haematobia in Kwale supported by the Kenya-Japan Communicable Diseases Control Project and sponsored by JICA and KEMRI. This paper is published with the permission of the Director, KEMRI.

We are grateful to Ms. Hannah Kariuki, Mr. Juma Mwatasa and the other staff of KEMRI and officers of Kwale District who co-operated in our study. We would like to express gratitude to the villagers in Mtsangatamu for their participation. We are also grateful to Dr. Masahiro Hashizume for valuable comments and Dr. Noboru Minakawa for his support in this research.

\section{FINANCIAL SUPPORT}

This work was supported partially by Foundation for Advanced Studies on International Development (FASID).

\section{REFERENCES}

1 . Chitsulo L, Engels D, Montresor A, Savioli L. (2000) The global status of schistosomiasis and its control. Acta Trop 77: 41-51.

2 . King CH. (2006) Long-term outcomes of school-based treatment for control of urinary schistosomiasis: a review of experience in Coast Province, Kenya. Mem Inst Oswaldo Cruz 101 Suppl 1: 299-306.

3 . King CH, Dickman K, Tisch DJ. (2005) Reassessment of the cost of chronic helmintic infection: a meta-analysis of disability-related outcomes in endemic schistosomiasis. Lancet 365: 1561-1569.

4. van der Werf MJ, de Vlas SJ, Brooker S, Looman CW, Nagelkerke NJ, Habbema JD, Engels D. (2003) Quantification of clinical morbidity associated with schistosome infection in sub-Saharan Africa. Acta Trop 86: 125-139.

5 . World Health Organization. (1985) The control of schistosomiasis. Report of a WHO Expert Committee. World Health Organ Tech Rep Ser 728: 1-113.

6 . Subramanian AK, Mungai P, Ouma JH, Magak P, King CH, Mahmoud AA, King CL. (1999) Long-term suppression of adult bladder morbidity and severe hydronephrosis following selective population chemotherapy for Schistosoma haematobium. Am J Trop Med Hyg 61: 476-481.

7 . Blanchard TJ. (2004) Schistosomiasis. Travel Med Infect Dis 2: 5-11.

8 . World Health Organization. (2002) The prevention and control of schistosomiasis and soil-transmitted helminthiasis. Report of a WHO Expert Committee. World Health Organ Tech Rep Ser 912: 1-57.

9 . Kabatereine NB, Fleming FM, Nyandindi U, Mwanza JC, Blair L. (2006) The control of schistosomiasis and soiltransmitted helminths in East Africa. Trends Parasitol 22: 332-339.

10 . Jordan P, Unrau GO, Bartholomew RK, Cook JA, Grist E. (1982) Value of individual household water supplies in the maintenance phase of a schistosomiasis control programme in Saint-Lucia, after chemotherapy. Bull World Health Organ 60: 583-588.

11. Noda S, Shimada M, Sato K, Ouma JH, Thiongo FW, Muhoho ND, Sato A, Aoki Y. (1988) Effect of mass chemotherapy and piped water on numbers of Schistosoma haematobium and prevalence in Bulinus globosus in Kwale, Kenya. Am J Trop Med Hyg 38: 487-495.

12 . Coura JR. (1995) Control of schistosomiasis in Brazil: perspectives and proposals. Mem Inst Oswaldo Cruz 90: 257260.

13. Muchiri EM, Ouma JH, King CH. (1996) Dynamics and control of Schistosoma haematobium transmission in Kenya: an overview of the Msambweni Project. Am J Trop 
Med Hyg 55, 5 Suppl: 127-134.

14. Gazzinelli A, Velasquez-Melendez G, Crawford SB, LoVerde PT, Correa-Oliveira R, Kloos H. (2006) Socioeconomic determinants of schistosomiasis in a poor rural area in Brazil. Acta Trop 99: 260-271.

15. Lima e Costa MF, Magalhaes MH, Rocha RS, Antunes CM, Katz N. (1987) Water-contact patterns and socioeconomic variables in the epidemiology of schistosomiasis mansoni in an endemic area in Brazil. Bull World Health Organ 65: 57-66.

16. Kloos H, Gazzinelli A, Van Zuyle P. (1998) Microgeographical patterns of schistosomiasis and water contact behavior; examples from Africa and Brazil. Mem Inst Oswaldo Cruz 93 Suppl 1: 37-50.

17 . Bethony J, Williams JT, Kloos H, Blangero J, Alves-Fraga L, Buck G, Michalek A, Williams-Blangero S, Loverde PT, Correa-Oliveira R, Gazzinelli A. (2001) Exposure to Schistosoma mansoni infection in a rural area in Brazil. II: household risk factors. Trop Med Int Health 6: 136-145.

18. Mason PR, Tswana SA. (1984) Single-dose metrifonate for the treatment of Schistosoma haematobium infection in an endemic area of Zimbabwe. Am J Trop Med Hyg 33: 599601.

19. Noda S, Shimada M, Muhoho ND, Sato K, Kiliku FB, Gatika SM, Waiyaki PG, Aoki Y. (1997) Effect of piped water supply on human water contact patterns in a Schistosoma haematobium-endemic area in Coast Province, Kenya. Am J Trop Med Hyg 56: 118-126.

20. el Kholy H, Arap Siongok TK, Koech D, Sturrock RF, Houser H, King CH, Mahmoud AA. (1989) Effects of borehole wells on water utilization in Schistosoma haematobium endemic communities in Coast Province, Kenya. Am J Trop Med Hyg 41: 212-219.

21. Muhoho ND, Katsumata T, Kimura E, Migwi DK, Mutua WR, Kiliku FM, Habe S, Aoki Y. (1997) Cercarial density in the river of an endemic area of schistosomiasis haematobia in Kenya. Am J Trop Med Hyg 57: 162-167.

22. Muhoho ND, Shimada M, Kimura E, Noda S, Sato K, Nderitu W, Kiliku F, Habe S, Gatika SM, Takahashi K, Tsukamoto A, Aoki Y. (1994) Changes in prevalence and intensity of Schistosoma haematobium infection after control measures in Mtsangatamu and Mwachinga. Proceeding of the symposium on epidemiology and control of schistosomiasis. Nairobi: JICA Kenya Office, 36-41.

23. Peters PA, Mahmoud AA, Warren KS, Ouma JH, Siongok TK. (1976) Field studies of a rapid, accurate means of quantifying Schistosoma haematobium eggs in urine samples. Bull World Health Organ 54: 159-162.

24 . Barbosa FS, Pinto R, Souza OA. (1971) Control of schistosomiasis mansoni in a small north east Brazilian community. Trans $R$ Soc Trop Med Hyg 65: 206-213. 